essentially identical with the "physical" forces responsible for the coherence of the solid as a whole.

Though only one chapter (VIII) deals specifically with the silicates, its expansion is implicit in the earlier chapters, where structures are illustrated by reference to diamond, zinc blende (with wurtzite), halite, fluorite, rutile, spinel, etc. The last three chapters are more strictly chemical, but sections dealing with hydrous minerals (e.g. zeolites and gypsum), the $\mathrm{OH}$-group, and the unique role of the $\mathrm{H}$-ion are of interest to the mineralogist.

Among the many illuminating points made, two are of special importance: they deny the validity of regarding silicates (and carbonates) as the salts of hypothetical silicic (and carbonic) acids, the silicic acids " simply have no existence" (p. 244) ; this conclusion is extended also to carbonic acid (p. 168).

Though numerous problems await solution, the volume of ascertained fact is impressive, and this exposition of it will commend itself strongly to students of mineralogy and petrology alike.

A. B.

\title{
CORRESPONDENCE.
}

\section{THE AGE OF THE UPPER BASALTS IN MIDDLE NORTHERN ICELAND.}

SIR,-In your June issue (p. 233) Dr. Helgi Pjeturss reaffirms his view that the upper basalts ("Grey Stage") of middle northern Iceland, regarded by me as early Tertiary, are of Quaternary age. The rocks in Fnjóskadal, the age and origin of which are in question, can be reached in a day from Akureyri-a common port of call for Icelandic passenger vessels-and it is to be hoped that other geologists will examine and report upon them. As the matter is of such fundamental importance in the reading of Icelandic geology $I$ add the following to the considerations advanced in my paper (GEol. MAG., 1938, p. 289).

At Tjörnes the sequence of events preceding the formation of the Quaternary rocks is seen to be : (1) tilting and planation of the early Tertiary rocks; (2) deposition of 1,500 feet of marine Pliocene sediments, followed by the outpouring of a lava series 300 feet thick ; (3) further earth movement and erosion. Now if the "Grey Stage" basalts only 20 miles from Tjörnes are Quaternary, where beneath them are the Pliocene rocks, and where are the unconformities? I am unaware of any evidences of them in the 2,000 feet of pre-" Grey Stage" rocks exposed in the valley sides. I agree with the view advanced by Dr. Pjeturss in 1905 that the Pliocene sediments were deposited in an arm of the sea which penetrated an already down-faulted tract, and that the relationship 
of the "Grey Stage" basalts of the highland to the low-lying Pliocene deposits shows " in the clearest manner" $(O \mathrm{~m}$ Islands Geologi, p. 34) that the "Grey Stage" is pre-Pliocene.

Dr. Pjeturss refers to the work of J. H. Lindal who has discovered inter-glacial sediments and basalts in Viðidal, north Iceland (Abstr. Proc. Geol. Soc. Lond., June, 1939, p. 104). According to Lindal these deposits with their covering basalts rest unconformably upon the floor of a broad valley over 2,000 feet below the plateau surface, and when they were laid down the essential features of the valley as it exists to-day were already in being. This occurrence affords no support to the hypothesis of the Quaternary age of the upper basalts of the plateau.

As Dr. Pjeturss refers to the pioneer work in which he has proved the great extent and thickness of the Quaternary formation in Iceland this is an opportunity to record the great appreciation which all students of Icelandic geology have of the value of his researches. I only differ from him in respect to his interpretation of the rocks in the middle northern part of the country.

L. Hawkes.

\section{ANNOUNCEMENT.}

The Albert Medal of the Royal Society of Arts for 1939 has been awarded, with the approval of the President, H.R.H. the Duke of Connaught, to Sir Thomas H. Holland, K.C.S.I., K.C.I.E., D.Sc., LL.D., F.R.S., "for his services to the mineral industries." 